\title{
PENGARUH SUBSTITUSI TEPUNG DAGING IKAN LELE DUMBO (CLARIAS GARIEPINUS) DAN TEPUNG UBI JALAR KUNING (IPOMOEA BATATAS L.) TERHADAP KANDUNGAN ZAT GIZI DAN PENERIMAAN BISKUIT BALITA TINGGI PROTEIN DAN B-KAROTEN
}

\author{
Imandira P.A.N, Fitriyono Ayustaningwarno*) \\ Program Studi Ilmu Gizi Fakultas Kedokteran Universitas Diponegoro \\ Jl.Dr.Sutomo No.14, Semarang, Telp (024) 8453708, Email : gizifk@undip.ac.id
}

\begin{abstract}
Background: PEM and vitamin A deficiencies had strong association. Suplementary Food Program (PMT) with high protein and vitamin A were given to child under five to prevent PEM and vitamin A deficiencies problem. King catfish is high protein food, while orange-fleshed sweet potato had high $\beta$-carotene content. Biscuits with substitution of king catfish flour and orange-fleshed sweet potato flour were expected to be alternative food for high protein and $\beta$-carotene PMT.

Objective: To determine effect of king catfish flour and orange-fleshed sweet potato flour substitution to nutrition content and acceptance of high protein and $\beta$-carotene biscuit for children under five's.

Methods: Randomized experimental study one of factor design with five levels of king catfish flour and orangefleshed sweet potato flour substitution, which were 0\%:0\%, 15\%:8\%, 15\%:10\%, 20\%:8\%, and 20\%:10\%. Nutrient content were analyzed is protein, energy, and $\beta$-carotene. Statistic analysis of nutrient content by One Way ANOVA followed by Tukey test, while acceptance by Friedman test followed Wilcoxon test.

Results: The highest of protein content is biscuits with $20 \%$ king catfish flour substitution $(19,81 \%$ and $20,8 \%)$ and the highest of $\beta$-carotene content is biscuits with $10 \%$ orange fleshed sweet potato flour substitution $(463,38 \mu \mathrm{g}$ dan $479,12 \mu \mathrm{g} / 100 \mathrm{~g})$. Variety of king catfish flour and orange-fleshed sweet potato flour substitution had significant effect on protein, energy, $\beta$-carotene content and color, aroma, texture, and taste of biscuits.

Conclusions: King catfish flour substitution increasing protein content, while orange-fleshed sweet potato flour substitution increasing $\beta$-carotene of biscuits. King catfish flour and orange-fleshed sweet potato flour substitution can lower the acceptance of biscuit's color, aroma and taste.However, the texture of biscuits $100 \%$ wheat flour or biscuits substitution assessed liked by the panelists.
\end{abstract}

Keyword: biscuits; catfish flour; orange-fleshed sweet potato flour; protein; energy; $\beta$-carotene

\section{ABSTRAK}

Latar Belakang: KEP dan defisiensi vitamin A memiliki hubungan yang erat. Pemberian Makanan Tambahan tinggi protein dan vitamin A perlu diberikan pada balita untuk mencegah masalah KEP dan defisiensi vitamin A. Ikan lele dumbo merupakan bahan pangan tinggi protein, sedangkan ubi jalar kuning tinggi akan kandungan $\beta$ karoten. Biskuit yang disubstitusi dengan tepung daging ikan lele dumbo dan tepung ubi jalar kuning diharapkan dapat menjadi alternatif makanan tambahan tinggi protein dan $\beta$-karoten.

Tujuan: Menganalisis pengaruh substitusi tepung daging ikan lele dumbo dan tepung ubi jalar kuning terhadap kandungan zat gizi dan penerimaan biskuit balita.

Metode: Merupakan penelitian eksperimental rancangan acak lengkap satu faktor dengan 5 taraf perlakuan substitusi tepung daging ikan lele dumbo dan tepung ubi jalar kuning yaitu 0\%:0\%, 15\%:8\%, 15\%:10\%, 20\%:8\%, dan 20\%:10\%. Kandungan zat gizi yang dianalisis antara lain kadar protein, energi dan $\beta$-karoten. Analisis statistik kandungan gizi menggunakan uji One Way ANOVA dilanjutkan posthoc test Tukey. Analisis penerimaan menggunakan uji Friedman dan Wilcoxon.

Hasil: Kadar protein tertinggi terdapat pada biskuit substitusi $20 \%$ tepung daging ikan lele dumbo $(19,81 \%$ dan $20,8 \%)$ dan kadar $\beta$-karoten tertinggi terdapat pada biskuit substitusi $10 \%$ tepung ubi jalar kuning $(463,38 \mu g$ dan $479,12 \mu \mathrm{g} / 100 \mathrm{~g})$. Variasi persentase substitusi tepung daging ikan lele dumbo dan tepung ubi jalar kuning berpengaruh terhadap kadar protein, energi, $\beta$-karoten serta terhadap warna, aroma, tekstur, dan rasa biskuit.

Kesimpulan: Substitusi tepung daging ikan lele dumbo meningkatkan kadar protein dan tepung ubi jalar kuning meningkatkan kadar $\beta$-karoten pada biskuit. Substitusi tepung daging ikan lele dumbo dan tepung ubi jalar kuning dapat menurunkan penerimaan warna, aroma dan rasa biskuit. Sementara itu, tekstur biskuit 100\% terigu dan biskuit substitusi dinilai suka oleh panelis.

Kata Kunci: biskuit; tepung ikan lele dumbo; tepung ubi jalar; protein; energi; $\beta$-karoten

\footnotetext{
${ }^{*}$ Penulis Penanggungjawab
} 


\section{PENDAHULUAN}

Kurang Energi Protein (KEP) merupakan salah satu masalah gizi utama di Indonesia. Salah satu kelompok usia yang rentan terhadap masalah KEP adalah kelompok usia balita. ${ }^{1}$ Berdasarkan Riset Kesehatan Dasar (Riskesdas) tahun 2010, prevalensi balita gizi buruk sebanyak $4,9 \%$ dan balita gizi kurang sebanyak $13 \%$. Secara Nasional dari tahun 2007 sampai pada tahun 2010 prevalensi balita gizi buruk dan gizi kurang menurun sebanyak $0,5 \%$, namun masih terdapat 17 provinsi di Indonesia yang memiliki angka prevalensi gizi buruk dan gizi kurang termasuk dalam kategori tinggi. $^{2}$

Kurang energi protein (KEP) dan defisiensi vitamin A memiliki hubungan yang erat. KEP pada balita dapat menimbulkan defisiensi vitamin A karena rendahnya asupan protein biasanya diikuti oleh rendahnya asupan vitamin A, selain itu dapat mengakibatkan terhambatnya absorpsi, transportasi, dan konversi vitamin A. Demikian juga defisiensi vitamin A yang ditimbulkan dapat menurunkan sistem kekebalan tubuh,sehingga meningkatkan risiko penyakit infeksi yang dapat memperburuk kejadian KEP pada balita. ${ }^{3,4}$

Pemberian Makanan Tambahan (PMT) balita merupakan salah satu upaya perbaikan pola konsumsi pada usia balita untuk mencegah kejadian KEP di Indonesia. ${ }^{5}$ Syarat kandungan gizi makanan tambahan balita diantaranya mengandung energi 400 kalori, 15-20 gram protein dan kadar vitamin A 266,7 $\mu \mathrm{g}$ RE per 100 gram serta diberikan dalam bentuk pangan lokal berupa makanan kudapan., ${ }^{5,6}$ Protein dibutuhkan untuk mengganti jaringan yang rusak, deposit jaringan otot dan berperan dalam pertumbuhan sel, sedangakan vitamin A berperan dalam fungsi sistem imunitas dan memelihara integritas sel-sel epitel. $^{7}$

Biskuit dapat dijadikan sebagai makanan tambahan untuk balita. ${ }^{5}$ Tingkat konsumsi biskuit dari tahun 1998 sampai tahun 2002 mengalami peningkatan yaitu dari 456,27 gram per kapita per tahun menjadi 576,19 gram per kapita per tahun dan diperkirakan akan terus mengalami peningkatan. $^{8}$

Pada kenyataannya biskuit yang diberikan sebagai PMT balita masih berupa biskuit berbahan dasar tepung terigu, dimana produksi tepung terigu di Indonesia masih bergantung pada gandum impor. Selain itu, tepung terigu tidak mengandung vitamin A serta kandungan protein yaitu 9g/100g. Lisin merupakan asam amino pembatas pada tepung terigu. Kandungan asam amino lisin tepung terigu yaitu $2,08 \mathrm{~g} / 16 \mathrm{~g} \mathrm{~N}{ }^{9}$

Salah satu bahan pangan sumber protein yang dapat dimanfaatkan sebagai bahan dalam pembuatan biskuit adalah ikan lele dumbo (Clarias gariepinus). ${ }^{10}$ Ikan lele dumbo merupakan ikan air tawar yang banyak dibudidayakan di Indonesia dan harga yang relatif terjangkau. Protein dalam ikan lele dumbo cukup tinggi yaitu sebesar $17 \%$. Kandungan asam amino ikan lele dumbo juga cukup lengkap terutama tinggi asam amino lisin yaitu $10,5 \% .{ }^{10}$ Namun, kandungan air dalam ikan lele dumbo sangat tinggi yaitu $76 \%$ menyebabkan daging ikan mudah rusak sehingga bentuk pengolahan ikan lele dumbo yang sesuai dalam pembuatan biskuit adalah penepungan. Kandungan protein pada tepung daging ikan lele dumbo cukup tinggi yaitu sebesar $63,83 \%{ }^{10}$ Berdasarkan penelitian Septiana, konsumsi biskuit tepung lele selama 88 hari berpengaruh terhadap perbaikan status gizi pada balita. ${ }^{11}$

Bahan pangan lokal yang kaya akan vitamin A perlu digunakan dalam pembuatan biskuit untuk memenuhi persyaratan kandungan vitamin A pada PMT balita. Ubi jalar kuning (Ipomoea batatas L.) merupakan salah satu bahan pangan lokal yang kaya akan karbohidrat dan $\beta$-karoten. Kandungan $\beta$-karoten dalam 100 gram ubi jalar kuning sebesar $2.900 \mu \mathrm{g} / 100 \mathrm{~g}$. Produksi ubi jalar kuning di Indonesia melimpah, sekitar 1.886 ton per tahun, tetapi tingkat konsumsinya masih tergolong rendah, yaitu sekitar $1,4-17,8 \%$. Penepungan dapat menjadi alternatif optimalisasi konsumsi pangan karena lebih fleksibel dan praktis dalam pengolahan produk makanan termasuk dalam pembuatan bikuit. ${ }^{12}$

Berdasarkan latar belakang tersebut maka dilakukan penelitian mengenai pengaruh substitusi tepung daging ikan lele dumbo (Clarias gariepinus) dan tepung ubi jalar kuning (Ipomoea batatas L.) terhadap kandungan zat gizi dan penerimaan biskuit balita.

\section{METODE}

Penelitian yang dilakukan ditinjau dari segi keilmuan termasuk dalam bidang Food Production. Penelitian ini dilaksanakan pada bulan Agustus hingga September 2012 di Laboratorium Teknologi Pangan Fakultas Ilmu Kesehatan Universitas Muhammadiyah Semarang.

Penelitian ini merupakan penelitian eksperimental dengan rancangan acak lengkap satu faktor. Terdapat 5 taraf perlakuan berupa biskuit kontrol dan biskuit dengan berbagai persentase 
substitusi tepung daging ikan lele dumbo dan tepung ubi jalar kuning. Persentase substitusi tepung daging ikan lele dumbo dan tepung ubi jalar kuning ditentukan berdasarkan estimasi perhitungan total kandungan zat gizi bahan baku pembuatan biskuit dengan mempertimbangkan persyaratan kadar protein,energi dan vitamin A pada makanan tambahan balita menggunakan program NutriSurvey for Windows 2005.

Setiap perlakuan dilakukan 3 kali pengulangan dan kandungan gizi dianalisis secara duplo. Penerimaan terhadap panelis dilakukan 1 kali pengujian. Perlakuan dalam penelitian ini dapat dilihat pada Tabel 1.

Tabel 1. Perlakuan Biskuit Balita Substitusi Tepung Daging Ikan Lele Dumbo dan Tepung Ubi Jalar Kuning

\begin{tabular}{lll}
\hline Jenis Perlakuan & \multicolumn{2}{l}{ Jenis Bahan } \\
\cline { 2 - 3 } & $\begin{array}{l}\text { Tepung } \begin{array}{c}\text { Daging } \\
\text { Ikan Lele Dumbo }\end{array} \\
\text { Tepung }\end{array}$ & Kuning \\
\hline K & $0 \%$ & $0 \%$ \\
P1 & $15 \%$ & $8 \%$ \\
P2 & $15 \%$ & $10 \%$ \\
P3 & $20 \%$ & $8 \%$ \\
P4 & $20 \%$ & $10 \%$ \\
\hline
\end{tabular}

Pembuatan biskuit balita substitusi tepung daging ikan lele dumbo dan tepung ubi jalar kuning dilakukan dengan proses pencampuran bahan dengan metode krim, pengadonan, pencetakan dan pemanggangan. Tepung daging ikan lele dumbo yang digunakan adalah hasil penepungan ikan lele dumbo (Clarias gariepinus) yang berasal dari pusat perikanan di Sawitan Kabupaten Magelang dengan berat 100 - 250 gram per ekor dan dibuat dengan cara ikan lele diambil dagingnya membentuk fillet ikan lele dumbo, dikukus dengan tekanan tinggi (presto) pada suhu $121^{\circ} \mathrm{C}$ selama 2 jam, dipres, dikeringkan pada suhu $\pm 50^{\circ} \mathrm{C}$ selama \pm 12 jam, digiling, dan diayak dengan tingkat kehalusan \pm 60 mesh.$^{10}$ Sementara tepung ubi jalar kuning yang digunakan yaitu merupakan tepung komersial produksi PT. Rejeki Berkah Gunung Pati Semarang dimana ubi jalar yang dipakai adalah ubi jalar (Ipomoea batatas $L$.) berasal dari Gunung Pati yang diolah dengan cara ubi jalar dikupas dan dicuci bersih, diiris tipis, dikeringkan pada suhu $60^{\circ} \mathrm{C}$ selama 10 jam, digiling, dan diayak dengan tingkat kehalusan 100 mesh.

Pada penelitian ini, data yang dikumpulkan dari variabel terikat adalah kadar protein, energi, $\beta$ karoten serta penerimaan biskuit substitusi tepung daging ikan lele dumbo dan tepung ubi jalar kuning. Kadar protein biskuit diukur dengan metode Kjeldahl dan kadar $\beta$-karoten diukur dengan metode spektrofotometri. ${ }^{13}$ Kadar energi biskuit diperoleh dengan mengkonversi jumlah protein, lemak dan karbohidrat menjadi jumlah energi. ${ }^{13}$ Sementara itu, penilaian terhadap penerimaan menggunakan uji hedonik dengan kriteria penilaian lima skala hedonik yaitu $1=$ sangat tidak suka; $2=$ tidak suka; $3=$ netral; 4=suka; dan 5=sangat suka. Panelis dalam menilai penerimaan biskuit merupakan panelis agak terlatih yaitu mahasiswa Program Studi Ilmu Gizi Fakultas Kedokteran Universitas Diponegoro sebanyak 25 orang. Penilaian penerimaan meliputi warna, aroma, tekstur, dan rasa.

Pengaruh substitusi tepung daging ikan lele dumbo dan tepung ubi jalar kuning terhadap kadar protein, energi dan $\beta$-karoten biskuit diuji menggunakan One Way Anova dengan derajat kepercayaan $95 \%$ yang dilanjutkan dengan posthoc test Tukey untuk mengetahui beda nyata kandungan protein, energi dan $\beta$-karoten antar perlakuan. Sementara itu, data penerimaan menggunakan uji Friedman dan uji lanjut Wilcoxon.

\section{HASIL}

\section{Kadar Protein, Lemak, Karbohidrat, Energi dan $\beta$-karoten Biskuit Substitusi Tepung Daging Ikan Lele Dumbo dan Tepung Ubi Jalar Kuning}

Hasil analisis kadar protein, karbohidrat, lemak, energi dan $\beta$-karoten biskuit substitusi tepung daging ikan lele dumbo dan tepung ubi jalar kuning disajikan pada Tabel 2. 
Tabel 2. Rerata Kadar Protein, Lemak, Karbohidrat, Energi dan $\beta$-karoten Biskuit Substitusi Tepung Daging Ikan Lele Dumbo dan Tepung Ubi Jalar Kuning

\begin{tabular}{|c|c|c|c|c|c|c|c|}
\hline \multirow[t]{2}{*}{ Perlakuan } & \multicolumn{7}{|c|}{ Rerata Kandungan Zat Gizi } \\
\hline & $\begin{array}{l}\text { Protein } \\
(\%)\end{array}$ & & $\begin{array}{l}\text { Lemak } \\
(\%)\end{array}$ & & $\begin{array}{l}\text { Karbohidrat } \\
(\%)\end{array}$ & $\begin{array}{l}\text { Energi } \\
\text { (kkal/100g) }\end{array}$ & $\begin{array}{l}\beta \text {-karoten } \\
(\mu \mathrm{g} / 100 \mathrm{~g})\end{array}$ \\
\hline \multirow[t]{2}{*}{ K } & & & $14,74 \pm$ & & & & $0,02 \pm 0,00^{\mathrm{a}}$ \\
\hline & $8,64 \pm 0,86$ & & $0,45^{\mathrm{a}}$ & & $64,66 \pm 0,32^{\mathrm{a}}$ & $426,08 \pm 0,52^{\mathrm{a}}$ & \\
\hline \multirow[t]{2}{*}{$\mathrm{P} 1$} & 17,99 & \pm & $17,27 \pm$ & & & & $335,05 \pm 16,00^{b}$ \\
\hline & $0,39^{\mathrm{bc}}$ & & $0,77^{\mathrm{a}}$ & & $60,44 \pm 1,13^{b}$ & $469,50 \pm 3,60^{\mathrm{bc}}$ & \\
\hline \multirow[t]{2}{*}{$\mathrm{P} 2$} & 17,68 & \pm & 16,46 & \pm & & & $479,12 \pm 19,77^{\mathrm{c}}$ \\
\hline & $0,53^{\mathrm{b}}$ & & $0,54^{\mathrm{a}}$ & & $61,15 \pm 0,93^{\mathrm{ab}}$ & $463,52 \pm 3,60^{\mathrm{b}}$ & \\
\hline \multirow[t]{2}{*}{ P3 } & 20,80 & \pm & $22,15 \pm$ & & & & $336,75 \pm 7,87^{b}$ \\
\hline & $1,86^{\mathrm{c}}$ & & $0,66^{\mathrm{b}}$ & & $51,72 \pm 1,26^{\mathrm{c}}$ & $489,41 \pm 3,64^{\mathrm{d}}$ & \\
\hline \multirow[t]{3}{*}{ P4 } & 19,81 & \pm & $21,17 \pm$ & & & & 463,38 \\
\hline & $1,10^{\mathrm{bc}}$ & & $2,05^{\mathrm{b}}$ & & $53,48 \pm 2,57^{\mathrm{c}}$ & $466,44 \pm 10,85^{\mathrm{cd}}$ & $\pm 34,52^{\mathrm{c}}$ \\
\hline & $\mathbf{p}=0.000^{*}$ & & $\mathrm{p}=0.000$ & & $\mathrm{p}=0.000^{*}$ & $\mathrm{p}=0.000^{*}$ & $\mathrm{p}=0.000^{*}$ \\
\hline
\end{tabular}

Keterangan: Angka yang diikuti dengan huruf superscript berbeda (a,b,c, d) menunjukkan beda nyata.

Berdasarkan Tabel 2, Biskuit kontrol memiliki kadar protein, energi, dan $\beta$-karoten terendah dibandingkan dengan biskuit substitusi tepung daging ikan lele dumbo dan tepung ubi jalar kuning. Biskuit substitusi tepung daging ikan lele dumbo $20 \%$ memiliki kadar protein lebih tinggi dibandingkan dengan biskuit kontrol dan biskuit substitusi tepung daging ikan lele dumbo $15 \%$. Kadar energi biskuit substitusi tepung daging ikan lele dumbo dan tepung ubi jalar kuning berkisar antara 463,52 - 489,41 kkal per 100 gram. Sementara itu, kadar $\beta$-karoten biskuit substitusi tepung ubi jalar kuning $10 \%$ berbeda nyata dengan biskuit kontrol dan biskuit substitusi tepung ubi jalar kuning $8 \%$. Biskuit substitusi tepung ubi jalar kuning $10 \%$ memiliki kadar $\beta$-karoten lebih tinggi dibandingkan dengan biskuit kontrol dan biskuit sustitusi tepung ubi jalar kuning $8 \%$.

2. Penerimaan Biskuit Substitusi Tepung Daging Ikan Lele Dumbo dan Tepung Ubi Jalar Kuning

Hasil analisis penerimaan warna, aroma, tekstur, dan rasa biskuit substitusi tepung daging ikan lele dumbo dan tepung ubi jalar kuning disajikan pada Tabel 3.

Tabel 3. Rerata Penerimaan Warna, Aroma, Tekstur dan Rasa Biskuit Substitusi Tepung Daging Ikan Lele Dumbo dan Tepung Ubi Jalar Kuning

\begin{tabular}{|c|c|c|c|c|c|c|c|c|}
\hline \multirow{2}{*}{$\begin{array}{l}\text { Perlakua } \\
\mathrm{n}\end{array}$} & \multicolumn{2}{|l|}{ Warna } & \multicolumn{2}{|l|}{ Aroma } & \multicolumn{2}{|l|}{ Tekstur } & \multicolumn{2}{|l|}{ Rasa } \\
\hline & Rerata & Ket & Rerata & Ket & Rerata & Ket & Rerata & Ket \\
\hline K & $\begin{array}{l}4,60 \pm 0,5 \\
0^{\mathrm{a}}\end{array}$ & $\begin{array}{l}\text { Sangat } \\
\text { suka }\end{array}$ & $\begin{array}{l}4,04 \pm 0, \\
74^{\mathrm{a}}\end{array}$ & Suka & $\begin{array}{l}4,28 \pm 0,68 \\
\text { a }\end{array}$ & Suka & $\begin{array}{l}4,44 \pm 0,82 \\
\text { a }\end{array}$ & Suka \\
\hline P1 & $\begin{array}{l}3,20 \pm 0,7 \\
1^{\mathrm{b}}\end{array}$ & Netral & $\begin{array}{l}3,48 \pm 0, \\
71^{\mathrm{b}}\end{array}$ & $\begin{array}{l}\text { Netra } \\
1\end{array}$ & $\begin{array}{l}3,52 \pm 0,65 \\
\text { b }\end{array}$ & Suka & $\underset{\mathrm{bc}}{3,16 \pm 0,94}$ & Netral \\
\hline $\mathrm{P} 2$ & $\begin{array}{l}2,92 \pm 0,8 \\
6^{\mathrm{b}}\end{array}$ & Netral & $\begin{array}{l}3,20 \pm 0, \\
96^{\mathrm{b}}\end{array}$ & $\begin{array}{l}\text { Netra } \\
1\end{array}$ & $\begin{array}{l}3,64 \pm 0,70 \\
\mathrm{~b}\end{array}$ & Suka & $\begin{array}{l}3,48 \pm 0,71 \\
\mathrm{~b}\end{array}$ & Netral \\
\hline P3 & $\begin{array}{l}3,00 \pm 0,7 \\
1^{\mathrm{b}}\end{array}$ & Netral & $\begin{array}{l}3,16 \pm 0 \\
90^{\mathrm{b}}\end{array}$ & $\begin{array}{l}\text { Netra } \\
1\end{array}$ & $\begin{array}{l}3,52 \pm 0,71 \\
\mathrm{~b}\end{array}$ & Suka & $\begin{array}{l}3,28 \pm 0,84 \\
\mathrm{bc}\end{array}$ & Netral \\
\hline P4 & $\begin{array}{l}2,36 \pm 0,6 \\
4^{\mathrm{c}}\end{array}$ & $\begin{array}{l}\text { Tidak } \\
\text { suka }\end{array}$ & $\begin{array}{l}3,16 \pm 0, \\
75^{\mathrm{b}}\end{array}$ & $\begin{array}{l}\text { Netra } \\
1\end{array}$ & $\begin{array}{l}3,52 \pm 0,77 \\
\mathrm{~b}\end{array}$ & Suka & $\begin{array}{l}2,84 \pm 1,07 \\
\mathrm{c}\end{array}$ & Netral \\
\hline & $\begin{array}{l}\mathrm{p}=0.000 \\
*\end{array}$ & & $\begin{array}{l}\mathrm{p}=0.000 \\
*\end{array}$ & & $\mathrm{p}=0.000^{*}$ & & $\mathrm{p}=0.000 *$ & \\
\hline
\end{tabular}

Keterangan: Angka yang diikuti dengan huruf superscript berbeda (a,b,c, d) menunjukkan beda nyata. 
Tabel 3. menunjukkan bahwa penerimaan warna biskuit yang tertinggi terdapat pada biskuit kontrol $(\mathrm{K})$ yaitu dengan tingkat penilaian sangat suka, dan yang terendah terdapat pada biskuit substitusi tepung daging ikan lele dumbo 20\% dan tepung ubi jalar kuning $10 \% \quad(\mathrm{P} 4)$ yaitu dengan tingkat penilaian tidak suka. Sementara itu, biskuit P1, P2 dan P3 memiliki tingkat penilaian netral terhadap penerimaan warna.

Penerimaan aroma dan rasa biskuit yang tertinggi terdapat pada biskuit kontrol (K) yaitu dengan tingkat penilaian suka, sedangkan penerimaan aroma dan rasa seluruh biskuit substitusi tepung daging ikan lele dumbo dan tepung ubi jalar kuning yaitu biskuit P1,P2,P3 dan P4 dinilai netral oleh panelis.

Penerimaan tekstur biskuit kontrol (K) berbeda nyata dengan seluruh biskuit substitusi tepung daging ikan lele dumbo dan tepung ubi jalar kuning yaitu biskuit P1,P2,P3 dan P4, namun sama-sama memiliki penilaian suka oleh panelis.

Berdasarkan hasil analisis penerimaan, substitusi tepung daging ikan lele dumbo dan tepung ubi jalar kuning dapat menurunkan penerimaan warna, aroma dan rasa biskuit. Sementara itu, secara statistik ada pengaruh substitusi tepung daging ikan lele dumbo dan tepung ubi jalar kuning terhadap penerimaan panelis akan warna, aroma, tekstur dan rasa biskuit.

\section{PEMBAHASAN}

\section{Kadar Protein}

Hasil penelitian menunjukkan kadar protein biskuit substitusi tepung daging ikan lele dumbo dan tepung ubi jalar kuning berkisar antara 17,68-20,80\%. Kandungan protein dalam biskuit yang dihasilkan dapat memenuhi spesifikasi makanan tambahan untuk balita, yaitu kandungan protein biskuit sebesar 15-20g dalam $100 \mathrm{~g}$ biskuit. ${ }^{5,6}$

Substitusi tepung daging ikan lele dumbo dan tepung ubi jalar kuning berpengaruh secara nyata terhadap kadar protein biskuit. Sumber protein dalam pembuatan biskuit dalam penelitian ini sebagian besar berasal dari tepung daging ikan lele dumbo. Biskuit substitusi tepung daging ikan lele dumbo $20 \%$ baik pada biskuit P3 maupun biskuit P4 mengandung protein lebih tinggi dibanding biskuit substitusi tepung daging ikan lele dumbo $15 \%$ yaitu biskuit $\mathrm{P} 1$ dan biskuit $\mathrm{P} 2$. Hal ini menunjukkan bahwa semakin tinggi substitusi tepung daging ikan lele dumbo maka semakin meningkatkan kadar protein pada biskuit.

Kadar protein tepung terigu, tepung daging ikan lele dumbo dan tepung ubi jalar kuning dalam penelitian ini berturut-turut sebesar $9 \mathrm{~g}$, $57,53 \mathrm{~g}$ dan $0,41 \mathrm{~g}$ per $100 \mathrm{~g}$. Berdasarkan hasil penelitian Anggita, peningkatan kadar protein akan berpengaruh pada peningkatan kekerasan biskuit yang dihasilkan. ${ }^{14}$

Ikan lele dumbo merupakan sumber protein bermutu tinggi dimana kandungan asam amino ikan lele dumbo cukup lengkap. Ikan lele dumbo mengandung asam amino lisin tinggi, sedangkan asam amino pembatas pada serealia (terigu) dan ubi jalar kuning adalah asam amino lisin. ${ }^{9,10}$ Hasil perhitungan asam amino lisin pada biskuit substitusi tepung daging ikan lele dumbo dan tepung ubi jalar kuning berdasarkan data sekunder kadar asam amino esensial ikan lele dumbo dan ubi jalar kuning mengalami peningkatan. Hasil perhitungan asam amino lisin biskuit substitusi tepung daging ikan lele dumbo dan tepung ubi jalar kuning disajikan secara singkat pada tabel 4.

Tabel 4. Hasil Perhitungan Beberapa Asam Amino pada Biskuit Substitusi Tepung Daging Ikan Lele Dumbo dan Tepung Ubi Jalar Kuning Berdasarkan Data Sekunder. ${ }^{9}$

\begin{tabular}{lllll}
\hline $\begin{array}{l}\text { Jenis } \\
\text { Perlakuan }\end{array}$ & $\begin{array}{l}\text { Lisin } \\
(\mathrm{mg} / \mathrm{g} \mathrm{N})\end{array}$ & $\begin{array}{l}\text { Isoleusin } \\
(\mathrm{mg} / \mathrm{g} \mathrm{N})\end{array}$ & $\begin{array}{l}\text { Fenilalanin } \\
(\mathrm{mg} / \mathrm{g} \mathrm{N})\end{array}$ & $\begin{array}{l}\text { Leusin } \\
(\mathrm{mg} / \mathrm{g} \mathrm{N})\end{array}$ \\
\hline K & 130 & 266,25 & 307,5 & 436,25 \\
P1 & 302,556 & 208,16 & 225,61 & 397,682 \\
P2 & 296,36 & 193,76 & 210,53 & 376,21 \\
P3 & 368,34 & 206,13 & 218,44 & 413,47 \\
P4 & 362,145 & 193,14 & 203,35 & 392 \\
\hline
\end{tabular}


Berdasarkan kombinasi bahan-bahan tersebut, substitusi tepung daging ikan lele dumbo diharapkan dapat melengkapi kekurangan lisin pada terigu dan tepung ubi jalar dalam proses pembuatan biskuit.

\section{Kandungan Energi}

Berdasarkan hasil penelitian, substitusi tepung daging ikan lele dumbo dan tepung ubi jalar kuning berpengaruh nyata terhadap perubahan kandungan energi dalam biskuit. Kandungan energi pada biskuit substitusi tepung daging ikan lele dumbo dan tepung ubi jalar kuning diperoleh dengan mengkonversi kadar protein, lemak, dan karbohidrat menjadi jumlah energi. Lemak merupakan sumber energi yang paling besar, dimana 1 gram lemak dapat dikonversi menjadi energi sebesar 9 kkal.Sedangkan protein dan karbohidrat menghasilkan energi 4 kkal per gram. ${ }^{13}$

Berdasarkan hasil perhitungan, kandungan energi biskuit substitusi tepung daging ikan lele dumbo dan tepung ubi jalar kuning berkisar antara 463,52 kkal/100g - 489,41 kkal/100g. Menurut persyaratan makanan tambahan untuk balita dan SNI 01-7111.22005, kandungan energi minimal dalam biskuit adalah $400 \mathrm{kkal} / 100 \mathrm{~g}{ }^{15}$ Jika mengacu pada persyaratan tersebut, maka seluruh perlakuan biskuit substitusi tepung daging ikan lele dumbo dan tepung ubi jalar kuning berada diatas persyaratan minimun kandungan energi.

\section{Kadar $\beta$-karoten}

Kadar $\beta$-karoten biskuit substitusi tepung daging ikan lele dumbo dan tepung ubi jalar kuning berkisar antara 335,05 - 479,12 $\mu \mathrm{g} / 100 \mathrm{~g}$. Berdasarkan persyaratan biskuit bayi SNI 01-7111.2-2005 dan PMT balita dimana kandungan vitamin A minimal sebesar $250-266,7 \mu \mathrm{g} / 100 \mathrm{~g}$ ( setara kadar $\beta$-karoten $\pm 1500-1600,3 \mu \mathrm{g} / 100 \mathrm{~g}$ ), maka biskuit substitusi tepung daging ikan lele dumbo dan tepung ubi jalar kuning dalam penelitian ini belum memenuhi standar tesebut. ${ }^{15}$ Namun, seluruh biskuit substitusi tepung daging ikan lele dumbo dan tepung ubi jalar kuning berbeda nyata dengan biskuit $100 \%$ tepung terigu. Kadar $\beta$-karoten biskuit $100 \%$ tepung terigu hanya mengandung $\pm 0,02 \mu \mathrm{g} / 100 \mathrm{~g}$. Semakin tinggi substitusi tepung ubi jalar kuning maka cenderung semakin meningkatkan kadar $\beta$-karoten pada biskuit. ${ }^{16}$

$\beta$-karoten merupakan antioksidan yang berperan dalam fungsi sistem kekebalan, memelihara integritas sel-sel epitel, sistem penglihatan serta membantu pertumbuhan. ${ }^{7}$

Ubi jalar kuning mengandung kadar $\beta$ karoten cukup tinggi. Kurang lebih $89 \%$ total karoten ubi jalar kuning adalah $\beta$-karoten yang didominasi oleh bentuk trans- $\beta$-karoten. ${ }^{16}$ Proses pengolahan menjadi biskuit dapat menyebabkan kandungan $\beta$-karoten tersebut dapat berkurang dan mengalami kerusakan. Proses pengeringan yang dilakukan dengan pemanasan suhu tinggi berpotensi menurunkan kadar $\beta$-karoten serta kemungkinan adanya paparan oksigen akan menyebabkan oksidasi enzimatis terhadap $\beta$-karoten oleh enzim lipoksigenase yang akan mengoksidasi $\beta$ karoten sehingga menjadi bentuk hidroksi $\beta$ karoten, semikaroten, betakarotenon, aldehid, dan hidroksi betaneokaroten yang menyebabkan kerusakan molekul $\beta$-karoten all trans. ${ }^{17}$

Ubi jalar kuning dalam penelitian ini mengalami proses penepungan dengan metode pengeringan. Pada penelitian ini suhu pengeringan dalam pembuatan tepung ubi jalar kuning adalah $\pm 60^{\circ} \mathrm{C}$ selama \pm 10 jam dengan oven. Selain itu, pada saat pengolahan menjadi biskuit suhu pemanggangan yang digunakan yaitu $\pm 160^{\circ} \mathrm{C}$ selama 20 menit. Pengeringan ubi jalar menjadi tepung dan pemanggangan biskuit mempengaruhi penurunan kadar $\beta$-karoten karena pada proses ini terjadi pengolahan dengan suhu tinggi. Jumlah penurunan akan semakin besar seiring dengan bertambahnya suhu dan waktu pemanggangan. Selain itu, adanya kontak dengan udara bebas memungkinkan terjadinya oksidasi juga berperan dalam penurunan kadar $\beta$-karoten yaitu saat proses pemotongan serta penggilingan. ${ }^{18}$

\section{Penerimaan}

\section{a. Warna}

Penerimaan warna biskuit berbagai persentase substitusi tepung daging ikan lele dumbo dan tepung ubi jalar kuning berbeda nyata dengan biskuit $100 \%$ terigu. Hal ini dapat disebabkan karena biskuit substitusi tepung daging ikan lele dumbo dan tepung ubi jalar kuning menghasilkan warna kuning kecoklatan hingga coklat, sedangkan biskuit kontrol berwarna kuning cerah. Warna biskuit yang dihasilkan dipengaruhi oleh tepung daging ikan lele dumbo dan tepung ubi jalar kuning yang disubstitusikan. Warna tepung daging ikan 
lele dumbo yaitu coklat muda, sedangkan tepung ubi jalar kuning memiliki warna kuning pucat.

Derajat putih tepung daging ikan lele dumbo memiliki nilai yang lebih rendah daripada tepung terigu. Hal ini menunjukkan bahwa tepung daging ikan lele dumbo memiliki warna yang lebih gelap sehingga semakin tinggi substitusi tepung daging ikan lele dumbo menghasilkan biskuit yang semakin coklat. ${ }^{13}$ Warna coklat yang dihasilkan juga dipengaruhi oleh reaksi maillard pada proses pemanggangan. Reaksi Maillard merupakan reaksi browning non enzimatis antara asam amino bebas yang berikatan dengan gugus gula pereduksi seperti fruktosa, laktosa dan maltosa dalam suasana panas menyebabkan warna bahan makanan menjadi kecoklatan. Reaksi Mailard pada biskuit dapat terjadi karena proses pemanggangan dengan suhu di atas $115^{\circ} \mathrm{C}^{19,20}$

\section{b. Aroma}

Aroma biskuit substitusi tepung daging ikan lele dumbo dan tepung ubi jalar kuning dapat diterima panelis dengan penilaian netral. Penerimaan aroma antar biskuit substitusi tepung daging ikan lele dumbo dan tepung ubi jalar kuning tidak berbeda secara nyata, namun berbeda nyata dengan biskuit $100 \%$ terigu. Hal ini disebabkan karena biskuit substitusi tepung daging ikan lele dumbo dan tepung ubi jalar kuning memiliki aroma amis yang berasal ikan lele dumbo.

Substitusi tepung daging ikan lele dumbo yang tinggi dapat menyebabkan aroma amis yang relatif tajam. Pembuatan biskuit pada penelitian ini menggunakan vanili untuk mengurangi aroma amis yang berasal dari tepung daging ikan lele dumbo.

\section{c. Tekstur}

Tekstur semua biskuit substitusi tepung daging ikan lele dumbo dan tepung ubi jalar kuning pada penelitian ini memiliki penilaian suka oleh panelis. Penerimaan tekstur antar biskuit substitusi tepung daging ikan lele dumbo dan ubi jalar kuning tidak berbeda nyata, namun berbeda nyata dengan biskuit $100 \%$ terigu.

Biskuit yang dihasilkan memiliki tekstur padat dan renyah. Hal ini dipengaruhi oleh lemak yang memiliki efek shortening pada makanan yang dipanggang seperti biskuit, kue kering, dan roti sehingga menjadi lebih renyah. Kandungan lemak dalam biskuit sebagian besar berasal dari mentega, tepung daging ikan lele dumbo dan kuning telur. Kadar lemak tepung daging ikan lele dumbo sebesar 10,4 g/100g. Lemak akan memecah strukturnya kemudian melapisi pati dan gluten, sehingga dihasilkan biskuit yang renyah. Lemak dapat memperbaiki struktur fisik seperti pengembangan, kelembutan, tekstur, dan aroma. ${ }^{21}$

Selain itu, tekstur biskuit juga dipengaruhi oleh tingkat kehalusan dari tepung daging ikan lele dumbo dan tepung ubi jalar kuning. Pengayakan tepung ubi jalar kuning dilakukan dengan menggunakan ayakan 100 mesh sementara tepung daging ikan lele dumbo diayak dengan ayakan biasa \pm 60 mesh karena tepung daging ikan lele dumbo yang telah dihaluskan sedikit menggumpal sehingga tidak dapat diayak menggunakan ayakan 80 mesh. Adanya proses pemanasan dalam penepungan menyebabkan daging ikan lele dumbo menggumpal.

Tingkat kehalusan produk tepung yang umum dipersyaratkan minimal adalah 80 mesh. Salah satu kriteria kualitas tepung yang baik adalah apabila minimal $90 \%$ dari produk tersebut lolos ayakan 80 mesh. Sebagai perbandingan, tingkat kehalusan tepung terigu yang diperkenankan oleh SNI 01-3751-2006 adalah minimal $95 \%$ harus lolos ayakan 80 mesh. ${ }^{22}$

\section{d. Rasa}

Pada penelitian ini, biskuit seluruh perlakuan substitusi tepung daging ikan lele dumbo dan tepung ubi jalar kuning memiliki penilaian netral. Penerimaan panelis terhadap rasa biskuit seluruh perlakuan substitusi berbeda nyata dengan biskuit $100 \%$ terigu.

Selain rasa manis gurih yang berasal dari telur, gula dan mentega, biskuit substitusi tepung daging ikan lele dumbo dan tepung ubi jalar kuning juga memiliki after taste pahit. After taste pahit dapat disebabkan oleh hidrolisis asam-asam amino yang terjadi pada reaksi Maillard saat pembuatan tepung dan pemanggangan 
biskuit. ${ }^{10}$ Selain itu, substitusi tepung ubi jalar juga memberikan pengaruh rasa pahit pada biskuit. Rasa pahit pada tepung ubi jalar biasanya disebabkan oleh beberapa senyawa kimia seperti fenolik dan alkaloid. $^{14}$

\section{Rekomendasi Biskuit}

Kadar protein seluruh biskuit substitusi tepung daging ikan lele dumbo dan tepung ubi jalar kuning yaitu biskuit P1,P2,P3 dan P4 sudah memenuhi standar persyaratan minimal biskuit bayi SNI 017111.2-2005 dan standar makanan tambahan balita. Sementara itu, kadar $\beta$ karoten biskuit P1 dan P3 lebih rendah dari biskuit P2 dan P4.

Penerimaan aroma, tekstur dan rasa biskuit P1,P2,P3 dan P4 dapat diterima oleh panelis. Sementara itu, penerimaan warna biskuit $\mathrm{P} 1, \mathrm{P} 2$ dan $\mathrm{P} 3$ dapat diterima oleh panelis, namun warna biskuit P4 dinilai tidak suka oleh panelis.

Biskuit yang direkomendasikan adalah biskuit P2 yaitu biskuit substitusi tepung daging ikan lele dumbo $15 \%$ dan tepung ubi jalar kuning 10\%. Kadar protein biskuit P2 sudah memenuhi persyaratan minimal biskuit bayi SNI 017111.2-2005 dan standar makanan tambahan balita. Sementara itu, biskuit P2 memiliki kontribusi kadar $\beta$-karoten paling optimal dibandingkan biskuit lain, meskipun belum memenuhi standar makanan tambahan balita dan persyaratan biskuit bayi SNI 01-7111.2-2005. Hasil penelitian menunjukkan bahwa biskuit P2 dapat diterima panelis dari penilaian warna, aroma,tekstur dan rasa.

\section{SIMPULAN DAN SARAN}

\section{Simpulan}

1. Semakin tinggi substitusi tepung daging ikan lele dumbo maka semakin meningkatkan kadar protein pada biskuit.

2. Semakin tinggi substitusi tepung ubi jalar kuning maka semakin meningkatkan kadar $\beta$ karoten pada biskuit.

3. Substitusi tepung daging ikan lele dumbo dan tepung ubi jalar kuning dapat menurunkan penerimaan warna, aroma dan rasa biskuit. Sementara itu, tekstur biskuit $100 \%$ terigu dan biskuit substitusi dinilai suka oleh panelis.Warna biskuit substitusi tepung daging ikan lele dumbo dan tepung ubi jalar kuning menjadi semakin coklat, aroma agak amis,tekstur lebih padat,dan terdapat after taste agak pahit.

\section{Saran}

1. Perendaman ubi jalar kuning sebelum proses pengeringan dengan larutan metabisulfit $0,3 \%$ untuk melindungi $\beta$-karoten dari oksidasi dan peningkatan substitusi ubi jalar kuning agar syarat kadar $\beta$-karoten biskuit sebagai makanan tambahan balita dapat tercapai.

2. Pemberian perisa dalam pembuatan adonan biskuit substitusi tepung daging ikan lele dumbo dan tepung ubi jalar kuning untuk mengurangi after taste pahit.

3. Biskuit yang direkomendasikan adalah biskuit P2 yaitu biskuit substitusi tepung daging ikan lele dumbo $15 \%$ dan tepung ubi jalar kuning $10 \%$.

\section{DAFTAR PUSTAKA}

1. Ali Khomsan. Pangan dan Gizi untuk Kesehatan. Ed.1.Jakarta : Raja Grafindo Persada; 2004.p.2540.

2. Departemen Kesehatan Republik Indonesia. Laporan Hasil Riset Kesehatan Dasar (RISKESDAS) tahun 2010. Jakarta: Badan Penelitian dan Pengembangan Kesehatan; 2010.

3. Chandra RK. Nutrition and Immune System : An Introduction. Am J Clin Nutr: 4605-4635;1997.

4. Gallagher ML. The nutrients and their metabolism. In: Mahan LK, Escott-Stump S. Krause's food and nutrition theraphy. $12^{\text {th }}$ ed. Canada: Saunders Elsevier, 2008; p.64-69, 71-73.

5. Ditjen Bina Gizi dan Kesehatan Ibu dan Anak. Panduan Penyelenggaraan Pemberian Makanan Tambahan Bagi Balita Gizi Kurang. Jakarta : Kemenkes RI;2011.

6. FAO/WHO. Guidelines on Formulated Suplementary Food for Older Infants and Young Children. Roma : FAO/WHO;1994.

7. Trahms CM, McKean KN. Nutrition During Infancy. In Mahan LK, Escott-Stump S. Krause's Food and Nutrition Theraphy $12^{\text {th }}$ ed. Canada: Elsevier;2008.p.225-228.

8. Widayani.S. Efikasi dan Preferensi Biskuit yang Difortifikasi Vitamin A dan Zat Besi (Fe)dan Kaitannya dengan Konsumsi, Status Gizi dan Respon Imun Anak Balita [DISERTASI]. Bogor : Institut Pertanian Bogor;2007.

9. Deddy Muchtadi.Teknik evaluasi nilai gizi protein. Bandung: Alfabeta, 2010; p.72-145.

10. Mervina. Formulasi Biskuit dengan Substitusi Tepung Ikan Lele Dumbo (Clarias gariepinus) dan Isolat Protein Kedelai (Glycine max) sebagai Makanan Potensial Untuk Anak Balita Gizi Kurang [SKRIPSI]. Bogor : Institut Pertanian Bogor;2009. 
11. Dani Nugraha. Hubungan Kepatuhan Konsumsi Biskuit yang Diperkaya Protein Tepung Ikan Lele Dumbo (Clarias gariepinus) dengan Status Gizi dan Morbiditas Balita di Warungkiara, Bantargadung, Kabupaten Sukabumi. [SKRIPSI]. Bogor: Institut Pertanian Bogor;2008.

12. Indrie Ambarsari, Abdul Choliq. Rekomendasi dalam penetapan standar mutu tepung ubi jalar. Jurnal Standardisasi. 2009; 11(3): 212-219.

13. Association of Analytical Chemist [AOAC] publisher.2005.Official methodes of analysis of the associationof official analytical chemist.Arlington:Virginia USA:The Association of Official Analytical Chemist,Inc.

14. Anggita Widhi R. Kajian Formulasi Cookies Ubi Jalar ((Ipomoea batatas L.) ) dengan Karakteristik Tekstur Menyerupai Cookies Keladi [SKRIPSI]. Bogor: Institut Pertanian Bogor;2008.

15. Detail SNI MP-ASI Biskuit. [serial online]. 2005. [dikutip pada $12 \quad$ Februari 2012].AvailablefromURL:www.websisni.bsn.go.id /index.php\%3F/sni_main/sni/detail_sni/

16. Idolo I. Sensory and nutritional quality of madiga produced from composite flour of wheat and sweet potato. Pak J Nutr. 2011; 10(11): 1004-1007.

17. Lee, Chi-Ho, Jin-Kook Cho, Seung Ju Le, Wonbang Koh, Woojoon Park, Chang-Han Kim. Enhancing $\beta$-carotene content in asian noodles by adding pumpkin powder. Cereal Chem: 79(4); 593-5. 2002.

18. PJ Fellows. Food Processing Technology Principle and Practice. Cambridge England: Wood Publishing in Food Science and Technology. 2000.

19. Winarno. Kimia pangan dan gizi. Jakarta: PT Gramedia Pustaka Utama; 2002.p.59-65

20. Cauvain SP. Bread making improving quality. $1^{\text {st }}$ ed. Cambridge: Woodhead Publishing Limited, 2003 ; p.62.

21. Matz SA. Cookies and Crakers Technology The AVI Publishing Co. Inc. Westport. Connectricut. 2001.

22. Ambarsari I, Sarjana, Choliq A. Rekomendasi dalam Penetapan Standar Mutu Tepung Ubi Jalar. Ungaran: Balai Pengkajian Teknologi Pertanian (BPTP). 2009. 